\title{
Floral induction management in 'Palmer' mango using uniconazole
}

\author{
Manejo da indução floral da mangueira 'Palmer' com uso de uniconazole
}

\author{
Guilherme Machado de Sousa Lima ${ }^{\mathrm{I}}$ Marlon Cristian Toledo Pereira ${ }^{\mathrm{I}{ }^{*}}$ \\ Moacir Brito Oliveira ${ }^{\text {I }}$ Silvia Nietsche ${ }^{\text {II }}$ Gisele Polete MizobutsiI \\ Wilson Maciel Públio Filho ${ }^{I}$ Débora Souza Mendes ${ }^{I}$
}

\section{ABSTRACT}

The objective of this study was to evaluate the effects of different doses of uniconazole (UCZ) on 'Palmer' mango vegetative and reproductive response and on fruit physical, chemical, and productive characteristics during the off-season in northern Minas Gerais, Brazil. The experiment followed a randomized block design. UCZ was tested at the following doses applied to leaves and expressed in gof UCZ active ingredient (a.i.) per tree: 0.0, 1.0, and 1.0+1.0 (2.0) after 30 days; $1.0+1.0+1.0$ (3.0) subdivided into 30-day intervals; and 1.0+1.0+2.0 (4.0) subdivided into 30-day intervals. All of the UCZ treatments reduced branch elongation in the 'Palmer' mango trees, leading to a mean reduction of $81.6 \%$ compared to the control. However, the UCZ application of $1.0+1.0+2.0 \mathrm{~g}$ a.i. per tree subdivided into 30-day intervals was efficient in promoting flowering during the off-season, enabling a 167\% mean increase in the number of fruit

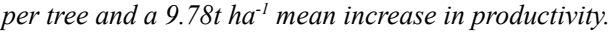

Key words: Mangifera indica, growth regulator, flowering, offseason crop, yield.

\section{RESUMO}

Este trabalho teve como objetivo avaliar a eficiência da aplicação de diferentes doses de uniconazole (UCZ) em mangueira 'Palmer' no comportamento vegetativo, reprodutivo e nas características físicas, químicas e produtivas dos frutos durante o periodo de entressafra na região Norte de Minas Gerais. $O$ delineamento experimental foi em blocos ao acaso, testandose as doses 0,$0 ; 1,0 ; 1,0+1,0$ (2,0) após 30 dias; 1,0+1,0+1,0 $(3,0)$ parcelado a cada 30 dias; $1,0+1,0+2,0(4,0)$ parcelado a cada 30 dias, em g, do ingrediente ativo (i.a.) de UCZ por planta, aplicado via foliar. Verificou-se que todos os tratamentos com uso de uniconazole reduziram o alongamento dos ramos da mangueira 'Palmer', quando comparada com a testemunha, apresentando uma redução média de $81,6 \%$, no entanto, apenas a aplicação de 1,0+1,0+2,0g i.a. UCZ/planta parcelado a cada 30 dias foi eficiente em promover a floração no período da entressafra possibilitando um incremento médio de $167 \%$ no número de frutos por planta e de 9,78t ha ${ }^{-1}$ na produtividade.

Palavras-chave: Mangifera indica, regulador vegetal, florescimento, entressafra, produtividade.

\section{INTRODUCTION}

The ability to produce crops throughout the entire year is of great interest for mango production under Brazilian semiarid conditions. The knowledge that canopy management in mango trees favor flowering, has guided studies on mango production to meet the demand of mango markets (MOUCO, 2010). Using the floral induction technique, by the use of uniconazole, paclobutrazole, pruning, water stress, potassium nitrate $\left(\mathrm{KNO}_{3}\right)$ or other techniques, allows farmers to obtain excellent quality fruit during any season of the year, permitting production to be scaled up during seasons with better market prices.

Mango trees flower for several months. The onset of flowering can be naturally or artificially altered by climatic conditions, the yield of previous harvest, or use of certain cultivation practices, such as application of growth regulators to induce flowering (DAVENPORT, 2007). Cool temperatures are important for mango floral induction under subtropical conditions, while tip pruning and foliar

IUniversidade Estadual de Montes Claros (UNIMONTES), Janaúba, MG, Brasil.

IDepartamento de Ciências Agrárias, Universidade Estadual de Montes Claros (UNIMONTES), 39440-000, Janaúba, MG, Brasil. E-mail: marlon.pereira@unimontes.br. "Corresponding author. 
applied $\mathrm{KNO}_{3}$ are effective methodologies that induce synchronous flowering (RAMÍREZ \& DAVENPORT, 2010; RAMÍREZ et al., 2010; SANDIP et al., 2015).

Growth regulator is any of various synthetic or naturally occurring plant substances (as an auxin or gibberellin) that regulate growth, while, a growth retardant is a chemical which causes reduction in height or volume of trees without a reduction in yield (SAITO et al., 2006). Gibberellins appear to be the most active growth hormones for regulating flowering in mango trees and other fruit tree crops. Studies indicated that high gibberellin levels inhibit flowering and stimulate plant growth, and declining levels of gibberellin promote flowering (DAVENPORT, 2007). Uniconazole (UCZ) is a triazole that can strongly reduce the growth of many trees; UCZ is thus considered a plant growth retardant (OSHIO \& IZUMI, 1986). Many growth retardant, such as chlormequat chloride and paclobutrazol, inhibit gibberellin synthesis. UCZ inhibits the conversion of kaurene into kaurenoic acid, which is a precursor of gibberellic acid (TAIZ \& ZEIGER, 2009).

Studies aimed to identify growth regulators that are not only efficient for the management of mango tree flowering and production but also applicable to leaves, minimizing residues in the soil and avoiding the use of inadequate quantities over the years, considered as priorities for mango crop (MOUCO et al., 2010). The growth retardant most commonly used for the management of mango tree flowering is paclobutrazol, which is efficient when applied to the soil but has the drawback of relatively high persistence in both soil and trees. Studies aiming to adjust the amount of growth retardants to each cultivar will allow the formulation of recommendations for more efficient applications, which can not only provide quality fruit production throughout the year but also reduce the risk of residues in the environment and in the crop.

Given the aforementioned analysis, the objective of this study was to evaluate the effects of different doses of uniconazole (UCZ) on 'Palmer' mango vegetative and reproductive response and on fruit physical, chemical, and productive characteristics during the off-season in northern Minas Gerais, Brazil.

\section{MATERIALS AND METHODS}

The experiment was conducted at a commercial orchard located within the irrigated perimeter of Gorutuba, municipality of Nova
Porteirinha, MG, Brazil, from July 2013 to June 2014. The climate at the experimental site is Aw according to the Köppen classification, characterized by dry winters and rainy summers, and the soil is classified as Haplic Cambisol.

Twenty uniform seven-year-old trees ('Palmer' cultivar) from the same plot were selected in their fifth crop season. The trees were spaced 5 $\mathrm{m}$ apart within rows, with a 7-m interrow distance. A localized microsprinkler irrigation system, which was based on monitoring the evapotranspiration of the crop and of the experimental area, was used. Fertilizers were applied according to the crop needs, guided by soil and leaf analyses.

The experiment followed a randomized block design, with five treatments and four replicates. The experimental plot was composed of one tree, and the treatments were spray applied. UCZ was tested at the following doses applied to leaves and expressed in $\mathrm{g}$ of $\mathrm{UCZ}$ active ingredient (a.i.) per tree: 0.0, 1.0, and 1.0+1.0 (2.0) after 30 days; $1.0+1.0+1.0$ (3.0) subdivided into 30-day intervals; and 1.0+1.0+2.0 (4.0) subdivided into 30-day intervals. The first UCZ application (7/30/2013) occurred when the second vegetative flush emerged and expanded after the last pruning (February 2013). UCZ was applied to the leaves at a spray volume of $2 \mathrm{~L}$ per tree, using a commercial source (UNI $50 \mathrm{SC}$ ) that contained $50 \mathrm{~g}$ $\mathrm{L}^{-1}$ of uniconazole-P.

Floral induction was managed equally for all treatments and included actions to aid branch maturation (water stress associated with three sprayings of $3 \%$ potassium sulfate at 10 -day intervals, with ethephon added to the last application at a concentration of $50 \mathrm{~mL} 100 \mathrm{~L}^{-1}$ of solution) and to break branch dormancy, stimulating and standardizing panicle emergence (deadheading on $12 / 03 / 2013$, combined with four applications of $2 \%$ calcium nitrate at seven-day intervals).

To implement the experiment, twelve branches per tree (three per quadrant) were randomly marked. Each quadrant corresponds to a cardinal point (North, South, East and West). These branches were used to calculate the new branch emergence percentage, and the length $(\mathrm{cm})$ and the diameter (mm) of new vegetative flushes were evaluated at 77 days after UCZ application. Relative chlorophyll content of the leaves was evaluated at 77 days after treatment application using four leaves per tree (one per quadrant) and a Minolta SPAD-502 (Soil-Plant Analysis Development) portable chlorophyll meter. Results were expressed in SPAD units. Branches were also used to calculate the number of panicles 
produced at 184 days after UCZ application during full flowering, which allowed an estimation of the flowered branch percentage for the entire tree.

The fruit were harvested on 5/08/2014 and 6/04/2014 at physiological maturity. Next, fruit were counted and weighed to determine the number and production of fruit per tree, which allowed the calculation of the mean fruit weight and yield. Four fruit per tree (one per quadrant) at medium tree height were randomly selected to evaluate the physical and chemical characteristics. These fruit were stored at the Postharvest Laboratory, State University of Montes Claros (Universidade Estadual de Montes Claros Unimontes) under ambient conditions for nine days until ripening enough for consumption, when the evaluations were performed. The physiological fruit maturity was obtained when the green areas of the mango turn to yellow as it ripens. Also the fruit was soft when squeezed gently.

The fruit sampled from each tree were individually weighed on the day they were harvested and at the time of consumption to determine the fresh weight loss. Length and diameter were measured using a caliper on the day the fruit were harvested; whereas, the following characteristics were evaluated at the time of consumption. Firmness was determined in the middle region of the unpeeled fruit using a texturometer with a 2-mm diameter probe. Color was determined by reflectometry using a Color Flex 45/0 (2200) colorimeter, stdzMode: 45/0, and expressed by lightness, chromaticity, and hue angle. Content of soluble solids was measured using a digital refractometer. The $\mathrm{pH}$ and titratable acidity also were evaluated. Sweetness was obtained from the ratio of the soluble solids to the titratable acidity values.

Statistical analyses were performed using SISVAR. The characteristics evaluated were subjected to analysis of variance, and their means were compared using Tukey's test at the 5\% probability level, except for the use of the $10 \%$ level for mean fruit production per tree and yield.

\section{RESULTS}

All of the UCZ treatments reduced the branch length. The highest branch growth inhibition was observed in the trees treated with 2.0, 3.0, and $4.0 \mathrm{~g}$ a.i. tree ${ }^{-1}$, namely, those trees receiving more than one UCZ application, which produced results that did not differ significantly from one other. Growth inhibition at these doses and respective application intervals led to an $81.63 \%$ mean reduction in branch length compared with the control. The mean branch diameter of trees from the 2.0 and $4.0 \mathrm{~g}$ a.i. tree $^{-1}$ treatments was significantly lower than trees in the control treatment (Figure 1).

The $4.0 \mathrm{~g}$ a.i. tree $^{-1}$ treatment, showing a mean of 2.0 panicles per branch, produced a significant increase in the number of panicles per branch in contrast to the control treatment. The same result was observed in the percentage of flowering trees in trees treated with the $4.0 \mathrm{~g}$ a.i. tree ${ }^{-1}$ dose showed flowering by $66.6 \%$ of branches, a percentage that differed significantly from the mean value of $20.8 \%$ showed by the control (Figure 1).

The treatments did not significantly differ regarding the emergence of new vegetative branches, exhibiting a mean of $63.75 \%$. Similarly, treatments did not differ regarding relative chlorophyll content, which averaged 55.56 SPAD units (Table 1).

Regarding the number of fruit per tree, only the $4.0 \mathrm{~g}$ a.i. tree $^{-1}$ treatment significantly differed from the others, exhibiting a mean that was $167 \%$ higher than the control. The greater amount of fruit on trees did not affect fruit weight, which averaged 468g (Table 1).

UCZ applied at the rate of $4.0 \mathrm{~g}$ a.i. tree $^{-1}$ divided into three applications led to higher fruit production per tree than that shown by the control. These results were reflected by the tree yields in that applying $4.0 \mathrm{~g}$ a.i. tree $^{-1}$ improved production by $9.78 \mathrm{tha}^{-1}$ compared with the control (Table 1 ).

Regarding fruit quality, the only physical or chemical characteristics analyzed that significantly differed among the treatments were fruit length and firmness (Table 1). The $3.0 \mathrm{~g}$ a.i. tree $^{-1}$ treatment divided into three applications resulted in smaller fruit compared with the control fruit. Fruit of trees treated with $2.0 \mathrm{~g}$ a.i. tree ${ }^{-1}$ divided into two applications were less firm compared with those harvested from trees that received no growth regulator.

\section{DISCUSSION}

Results indicated that $\mathrm{UCZ}$ reduced branch growth in 'Palmer' mango because of the ability of UCZ to inhibit gibberellin synthesis. Similar results were reported in studies with UCZ for 'Kent' (SILVA et al., 2010) and 'Palmer' (SILVA et al., 2014) mango. Most plant growth inhibitors reduced gibberellin synthesis and can thus be used to reduce branch elongation and to manage plant growth (MOUCO et al., 2010).

Gibberellins stimulated elongation and cell division; promoted fruiting, seed germination, and floral initiation; and influenced sex determination. 


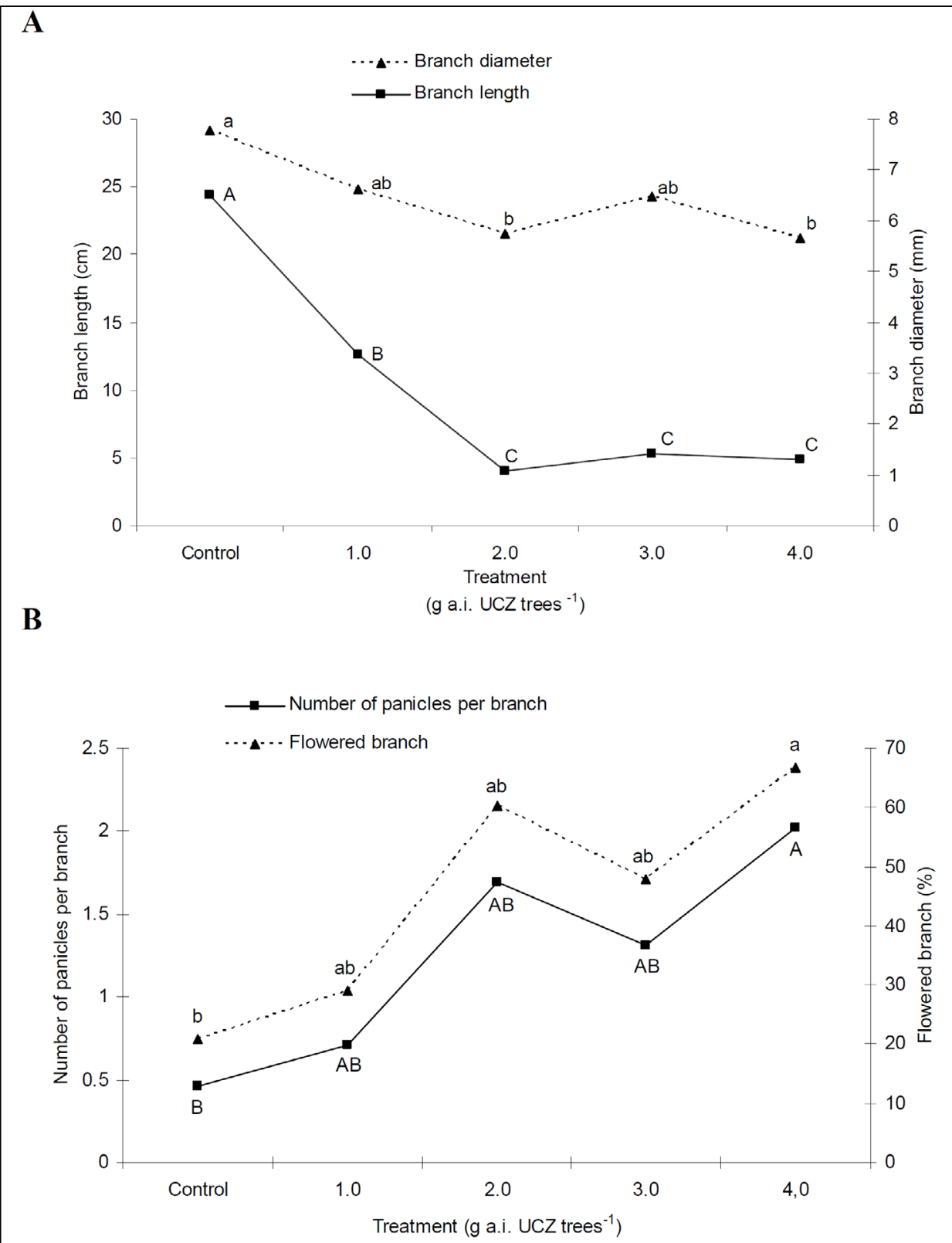

Means followed by the same capital letter and means followed by same lower letter do not differ significantly by Tukey's test at $\mathrm{P}<0.01$ (A) and $\mathrm{P}<0.05$ (B).

Figure 1 - Mean branch length (A), branch diameter (A), number of panicles per branch (B) and flowered branch percentage (B) of 'Palmer' mango using uniconazole (UCZ). Nova Porteirinha, Minas Gerais, Brazil. 2013/2014.

One of the most important physiological properties of gibberellins is their ability to induce flowering in trees kept under non inductive conditions (KERBAUY, 2004). Gibberellin biosynthetic pathway has three phases, each one occurring within a different cell compartment: plastids, endoplasmic reticulum, and cytosol. Growth retardants such as UCZ inhibit the second phase of gibberellin synthesis. At this phase, UCZ reaches the plants' subapical meristems, inhibiting the oxidation of kaurene into kaurenoic acid, which is the precursor of gibberellic acid (TAIZ \& ZEIGER, 2009). Physiological consequences are reduced plant growth and a higher availability of assimilable substances to the tree (DAVENPORT, 1994). 
Table 1 - Mean emergence of new vegetative branches (ENB), relative chlorophyll content (RCC), number of fruit per tree (NFT), mean frui1 weight (MFW), fruit production per tree (FPT), and yield (YIE) of 'Palmer' mango using uniconazole (UCZ); and mean length (LENG), diameter (DIAM), firmness (FIRM), soluble solids content (SS), pH, titratable acidity (TA), fresh weight loss (FWL), lightness (LIG), chromaticity (CHR), hue angle (HUE), and sweetness (SWE) of 'Palmer' mango fruits using uniconazole (UCZ). Nova Porteirinha, Minas Gerais, Brazil. 2013/2014.

\begin{tabular}{|c|c|c|c|c|c|c|}
\hline Treatment (g a.i. UCZ trees $^{-1}$ ) & ENB $(\%)$ & RCC (SPAD) & NFT & MFW (kg) & FPT $(\mathrm{kg})$ & YIE (kg/ha) \\
\hline 1- Control & $62.50 \mathrm{a}^{\mathrm{y}}$ & $55.67 \mathrm{a}^{\mathrm{y}}$ & $49.00 \mathrm{~b}^{\mathrm{y}}$ & $0.486 \mathrm{a}^{\mathrm{y}}$ & $23.65 \mathrm{~b}^{\mathrm{z}}$ & $6,740.25 b^{z}$ \\
\hline $2-1.0$ & $66.67 \mathrm{a}$ & $55.47 \mathrm{a}$ & $72.25 \mathrm{ab}$ & $0.496 \mathrm{a}$ & $35.75 \mathrm{ab}$ & $10,188.75 \mathrm{ab}$ \\
\hline $3-2.0(1.0+1.0)$ & $62.50 \mathrm{a}$ & $55.71 \mathrm{a}$ & $126.25 \mathrm{ab}$ & $0.449 \mathrm{a}$ & $57.20 \mathrm{ab}$ & $16,302.00 \mathrm{ab}$ \\
\hline $4-3.0(1.0+1.0+1.0)$ & $66.67 \mathrm{a}$ & $55.26 \mathrm{a}$ & $98.75 \mathrm{ab}$ & $0.468 \mathrm{a}$ & $45.38 \mathrm{ab}$ & $12,931.87 \mathrm{ab}$ \\
\hline $5-4.0(1.0+1.0+2.0)$ & $60.41 \mathrm{a}$ & $55.69 \mathrm{a}$ & $131.25 \mathrm{a}$ & $0.441 \mathrm{a}$ & $57.98 \mathrm{a}$ & $16,522.87 \mathrm{a}$ \\
\hline CV $(\%)$ & 34.30 & 2.60 & 36.45 & 6.87 & 39.56 & 39.56 \\
\hline
\end{tabular}

\begin{tabular}{|c|c|c|c|c|c|c|c|c|c|c|c|}
\hline $\begin{array}{l}\text { Treatment } \\
(\mathrm{g} \text { a.i. UCZ } \\
\left.\text { tree }^{-1}\right)\end{array}$ & $\begin{array}{l}\text { LENG } \\
(\mathrm{cm})\end{array}$ & $\begin{array}{l}\text { DIAM } \\
(\mathrm{cm})\end{array}$ & $\begin{array}{l}\text { FIRM } \\
(\mathrm{N})\end{array}$ & $\begin{array}{l}\text { SS } \\
\left({ }^{\circ} \text { Brix) }\right.\end{array}$ & $\mathrm{pH}$ & $\begin{array}{l}\text { TA (mg citric } \\
\text { acid per } 100 \\
\text { mL juice) }\end{array}$ & $\begin{array}{l}\text { FWL } \\
(\%)\end{array}$ & LIG & CHR & HUE & $\begin{array}{l}\text { SWE } \\
\text { (SS/TA) }\end{array}$ \\
\hline 1- Control & $14.09 \mathrm{a}^{\mathrm{y}}$ & $8.97 \mathrm{a}^{\mathrm{y}}$ & $145.27 \mathrm{a}^{\mathrm{y}}$ & $13.03 \mathrm{a}^{\mathrm{y}}$ & $3.47 \mathrm{a}^{\mathrm{y}}$ & $1.05 \mathrm{a}^{\mathrm{y}}$ & $8.45 \mathrm{a}^{\mathrm{y}}$ & $42.07 \mathrm{a}^{\mathrm{y}}$ & $25.89 \mathrm{a}^{\mathrm{y}}$ & $93.61 \mathrm{a}^{\mathrm{y}}$ & $12.82 \mathrm{a}^{\mathrm{y}}$ \\
\hline $2-1.0$ & $13.73 \mathrm{ab}$ & $8.94 \mathrm{a}$ & $118.70 \mathrm{ab}$ & $15.42 \mathrm{a}$ & $3.59 \mathrm{a}$ & $0.87 \mathrm{a}$ & $8.92 \mathrm{a}$ & $43.13 \mathrm{a}$ & $25.50 \mathrm{a}$ & $85.17 \mathrm{a}$ & $20.06 \mathrm{a}$ \\
\hline $\begin{array}{l}3-2.0 \\
(1.0+1.0)\end{array}$ & $13.63 \mathrm{ab}$ & $8.81 \mathrm{a}$ & $74.72 \mathrm{~b}$ & $15.52 \mathrm{a}$ & $3.70 \mathrm{a}$ & $0.95 \mathrm{a}$ & $7.79 \mathrm{a}$ & $40.16 \mathrm{a}$ & $24.34 \mathrm{a}$ & $82.86 \mathrm{a}$ & $17.88 \mathrm{a}$ \\
\hline $\begin{array}{l}4-3.0 \\
(1.0+1.0+1.0)\end{array}$ & $12.85 \mathrm{~b}$ & $8.51 \mathrm{a}$ & $95.06 \mathrm{ab}$ & $15.57 \mathrm{a}$ & $3.66 \mathrm{a}$ & $0.90 \mathrm{a}$ & $8.36 \mathrm{a}$ & $42.28 \mathrm{a}$ & $25.05 \mathrm{a}$ & $91.41 \mathrm{a}$ & $17.93 \mathrm{a}$ \\
\hline $\begin{array}{l}5-4.0 \\
(1.0+1.0+2.0)\end{array}$ & $13.38 \mathrm{ab}$ & $8.55 \mathrm{a}$ & $101.55 \mathrm{ab}$ & $15.52 \mathrm{a}$ & $3.66 \mathrm{a}$ & $0.91 \mathrm{a}$ & $8.65 \mathrm{a}$ & $42.18 \mathrm{a}$ & $24.33 \mathrm{a}$ & $93.19 \mathrm{a}$ & $18.31 \mathrm{a}$ \\
\hline CV (\%) & 3.28 & 3.58 & 21.18 & 10.83 & 6.03 & 22.4 & 10.59 & 6.81 & 17.95 & 13.52 & 32.97 \\
\hline
\end{tabular}

Means followed by the same letter do not differ significantly by Tukey's test at, ${ }^{\mathrm{y}} \mathrm{P}<0.05$, or ${ }^{\mathrm{z}} \mathrm{P}<0.10$.

The increased tree flowering treated with 4.0g a.i. UCZ was related to decreased branch growth, which most likely favored nutrient accumulation at the ends of the branches, stimulating them to mature. Mango trees only flower if certain correlated factors, such as nutrition, environmental temperature, and branch age, are in place. Flowering occurs in branches that are at least four months old under tropical conditions or three months old under mild temperature regimes (MOUCO, 2010). Generative shoot initiation in 'Keitt' trees occurred in $75 \%$ and $100 \%$ of the stems after $\mathrm{KNO}_{3}$ sprays applied 5 and 6 months after the pruning date, respectively. Tommy Atkins, a cultivar that is more difficult to induce to flower than 'Keitt', had $18 \%$ of shoots flowering after the 5-month application and 100\% flowering after the $\mathrm{KNO}_{3}$ application 6 months after the pruning date (RAMÍREZ \& DAVENPORT, 2010; RAMÍREZ et al., 2010). Based on this information, management of flowering and production requires that vegetative vigor be regulated to avoid new buds. Most mango farmers are interested in controlling mango tree flowering to obtain early production (DAVENPORT, 2007). Landmark stages for Tommy Atkins and Keitt, two cultivars commercially growing in the Americas, were observed in tropical orchards in Colombia. Aside from minor phenotypic differences in distinctive shoot and stem developmental stages, attempts to ascribe a distinct phenological pattern of mango tree growth and development are impractical. Each stem terminal or groups of stem terminals borne on scaffolding branches act as independent structures influenced by environmental conditions, such as temperature, water relations, and nutrition coupled with their physiological age resulting in widely variable tree responses even in similar environments (RAMÍREZ et al., 2014).

The higher flowering percentage in T5 (4.0g a.i. tree $\left.^{-1}\right)$ led to increased fruiting, which was reflected in the production. Paclobutrazol, a compound from the same class as UCZ, not only inhibits gibberellin synthesis, but also increases the proportion of hermaphrodite flowers in mango tree panicles and inhibits ethylene synthesis, resulting in a higher number 
of fruit retained on the branches (SINGH, 2001). The mean fruit weight did not differ among the treatments, suggesting that competition for photoassimilates in T5 did not compromise fruit quality in this treatment, which produced the highest number of fruit per tree. ALBUQUERQUE et al. (2008) reported that the application of the growth regulators chlormequat and UCZ on 'Italy' grape vines at concentrations of $1,500 \mathrm{mg} \mathrm{L}^{-1}$ and $30 \mathrm{mg} \mathrm{L}^{-1}$, respectively, favors nutrient accumulation and the differentiation of fertile buds, resulting in bunch production.

The triazole plant growth retardants, paclobutrazol and uniconazole, are expensive, and they can cause permanent stunting of flushes if trees are severely pruned at any time after soil application (DAVENPORT, 1994). Overdose may cause undesirable effects such as restricted growth, panicle malformation (too compact) and soot deformity (SWAMY, 2012). Studies of the impact of PBZ in fruit quality parameters are contradictory. MENDONÇA et al. (2003) reported no significant effect; however, SINGH \& RAM (2000) observed the PBZ increased quality fruits, so it was ascertained that the accumulation of $\mathrm{PBZ}$ residues on the surface or inside mango fruit (especially due applications of high rates) is unfriendly to human health. Continuous application of PBZ may cause soil pollution and its residual effect may increase in fruit. $\mathrm{PBZ}$ is persistent in the soil, so in this case UCZ applied by the leaves is less dangerous. In this research, we have conducted only one flowering season and fruiting and flowering were not evaluated on multiple seasons. It seems uniconazole has very negative effects after two or three flowering seasons (DAVENPORT, 1994).

There are no studies reporting the effect of UCZ on leaf chlorophyll content. However, some studies have positively correlated leaf chlorophyll content and readings provided by the SPAD-502 chlorophyll meter (AMARANTE et al., 2009). In the present study, it was expected that the higher UCZ amounts applied to the trees would result in higher relative foliar chlorophyll contents because of the reduced plant growth and a possible increased chlorophyll concentration in the leaves, which would have a darker green intensity; however, this result did not occur. It is possible that the collection of data 77 days after the first applications was insufficient to detect this effect.

Gibberellins are considered juvenility hormones for retarding fruit senescence and can retard chlorophyll degradation, increase the synthesis of carotenoids, and reduce the loss of tissue firmness, in addition to promoting longitudinal elongation (TAIZ
\& ZEIGER, 2009). Application of UCZ increased the number of fruit per tree, reducing their mean length because of competition for photoassimilates. Harvesting of fruit from all the treatments on the same day may have caused the control fruit to have been harvested at a less advanced maturation stage compared with that of the UCZ-treated fruit because this growth regulator promotes early mango flowering and fruiting, reducing the firmness of the UCZ-treated fruit. The other physical and chemical characteristics did not differ significantly among the treatments, indicating that fruit quality was not compromised by the UCZ treatments.

Floral induction of most plants involves sensing some environmental cue, i.e., day length, water stress, or vernalising temperature in some organs. In the tropics, however, the age of the last flush is the dominant factor regulating flowering. Stems must be in rest for sufficient time, generally about four to five months to be induced to flower in the absence of chilling temperatures. Tip pruning is ideal to synchronize vegetative flush events in the canopy. Nitrate salts (calcium, potassium or ammonium) applied to foliage stimulate shoot initiation (DAVENPORT, 2007; RAMÍREZ \& DAVENPORT, 2010; RAMÍREZ et al., 2010). It is necessary to identify plant growth regulators which might be applied to the leaves, so as to minimize the risk of residues in the soil and to avoid inadequate application levels over several years. Prohexadione-Ca, trinexapac-ethyl and chlormequat chloride at the dosage of $1.0 \mathrm{~g}$ a.i. plant $^{-1}$ acts on the regulation of vegetative growth in Tommy atkins young plants (MOUCO et al., 2010). However, more studies are required.

\section{CONCLUSION}

Uniconazole applied to leaves at the rate of $4.0 \mathrm{~g}$ a.i. tree ${ }^{-1}$ subdivided into three applications $(1.0+1.0+2.0)$ was efficient in promoting flowering and increasing fruit production in 'Palmer' mango during the off-season in the semiarid region of $\mathrm{MG}$, Brazil. However, this study could not prove the long term effects of uniconazole on tree flowering and yield. Also, uniconazole has to be used with caution because of its negative effects on soil microorganism and environmental issues.

\section{ACKNOWLEDGMENTS}

The authors thank the Agrogerais Farm for allowing the use of the experimental site and Fundação de Amparo à 
Pesquisa do Estado de Minas Gerais (FAPEMIG) for providing research grants and financing the study.

\section{REFERENCES}

ALBUQUERQUE, T.C.S. et al. Reguladores de crescimento vegetal na concentração de macronutrientes em videira Itália. Bragantia, Campinas, v.67, n.3, p.553-561, 2008. Available from: $<$ http://www.scielo.br/scielo.php?pid=S000687052008000300001\&script $=$ sci_arttext $>$. Accessed: Feb. 11, 2015. doi: 10.1590/S0006-87052008000300001.

AMARANTE, C.V.T. et al. Non-destructive quantification of area and chlorophyll content in the leaves of young 'Cabernet Sauvignon' grapevines. Revista Brasileira de Fruticultura, Jaboticabal, v.31, n.5, p.680-686, 2009. Available from: <http://www.scielo. br/scielo.php?pid=S0100-29452009000300009\&script $=$ sci arttext>. Accessed: Mar. 02, 2015. doi: 10.1590/S010029452009000300009.

DAVENPORT, T.L. Potential problems with use of uniconazole on mango (Mangifera indica). Plant Growth Regulation Society of America Quarterly, Alexandria, v.22, p.143-153, 1994

DAVENPORT, T.L. Reproductive physiology of mango. Brazilian Journal of Plant Physiology, Campos dos Goytacazes, v.19, n.4, p.363-376, 2007. Available from: <http://www.scielo. $\mathrm{br} / \mathrm{scielo} . \mathrm{php}$ ? pid $=\mathrm{S} 1677-04202007000400007 \& \mathrm{script}=\mathrm{sci}$ arttext $>$. Accessed: Jan. 30, 2015. doi: 10.1590/S167704202007000400007.

KERBAUY, G.B. Fisiologia vegetal. Rio de Janeiro: Guanabara Koogan, 2004. 452p.

MEDONCCA, V. et al. Utilization of paclobutrazol, ethephon and potassium nitrate in the flowering induction of mango in the semi arid northest. Revista Ciência e Agrotecnologia, Lavras, v.27, n.6, p. $1285-1292,2003$. Available from: $<$ http://www.scielo.br/ pdf/cagro/v27n6/12.pdf>. Accessed: Feb. 02, 2016.

MOUCO, M.A.C. Manejo da floração. In: EMPRESA BRASILEIRA DE PESQUISA AGROPECUÁRIA. Sistema de produção de manga, 2010. Available from: <http:// sistemasdeproducao.cnptia.embrapa.br/FontesHTML/Manga/ CultivodaMangueira_2ed/floracao.htm>. Accessed: Jan. 11, 2015.

MOUCO, M.A.C. et al. Synthesis inhibitors of gibberellins and mango 'Tommy Atkins' seedlings growth. Ciência Rural, Santa Maria, v.40, n.2, p.273-279, 2010. Available from: $\quad<$ http://www.scielo.br/scielo.php?script=sci arttext\&pid $=$ S0103-84782010000200004 $>$. Accessed: Jan. 30, 2015. doi: $10.1590 / \mathrm{S} 0103-84782010000200004$

OSHIO, H.; IZUMI, K. S-3307, a new plant growth retardant. Its biological activities, mechanism and mode of action. In: PLANT GROWTH REGULATORS IN AGRICULTURE. Food and fertilizer technology center book series. s.1.: s.ed., 1986. N.34, p.198-208.
RAMÍREZ, F.; DAVENPORT, T.L. Mango (Mangifera indica L.) flowering physiology. Scientia Horticulturae, Amsterdam, v.126, p.65-72, 2010. Available from: <http://www. sciencedirect.com/science/article/pii/S0304423810002992>. Accessed: Feb. 02, 2016.

RAMÍREZ, F. et al. The stem age required for floral induction of synchronized mango trees in the tropics. Hortscience, Alexandria, v.45, p.1453-1458, 2010. Available from: $<$ http://hortsci.ashspublications.org/content/45/10/1453.full. $\mathrm{pdf}+\mathrm{html}$ ? sid=3a3b2534-4625-4809-a033-fc75cdf61656>. Accessed: Feb. 02, 2016.

RAMÍREZ, F. et al. Mango trees have no distinct phenology: the case of mangoes in the tropics. Scientia Horticulturae, Amsterdam, v.168, p.258-266, 2014. Available from: <http:// www.sciencedirect.com/science/article/pii/S0304423814000661>. Accessed: Feb. 02, 2016.

SAITO, S. et al. A plant growth retardant, unizonazole, is a potent inhibitor of ABA catabolism in Arabidopsis. Bioscience, Biotechnology and Biochemistry, Tokyo, v.70, n.7, p.17311739, 2006. Available from: <http://www.tandfonline.com/doi/ pdf/10.1271/bbb.60077>. Accessed: Feb. 02, 2016.

SANDIP, M. et al. Physiology of flowering - the case of mango. International Journal of Applied Research, New Delhi, v.1, n.11, p.1008-1012, 2015. Available from: <http://www. allresearchjournal.com/archives/2015/vollissue11/PartO/1-111-2. pdf $>$. Accessed: Feb. 02, 2016.

SILVA, G.J.N. et al. Uniconazole on mango floral induction cultivar 'Kent' at submedio São Francisco region, Brazil. Acta Horticulturae, (ISHS), Leuven, n.884, p.677-682, 2010.

SILVA, K.K.A. et al. Uniconazole at flowering and production of mango (Mangifera indica L.) cv. 'Palmer'. Magistra, Cruz das Almas, v.26, n.4, p.507-517, 2014. Available from: $<$ http://www.ufrb.edu.br/magistra/2000-atual/volume-26ano-2014/numero-4-out-a-dez/artigos/1439-uniconazole-noflorescimento-e-producao-da-mangueira-mangifera-indica-1-cv>. Accessed: Mar. 02, 2015.

SINGH, D.K.; RAM, S. Level of paclobutrazol residues in shoot and fruit of mango. Indian Journal of Plant Physiology, New Delhi, v.5, p.186-188, 2000

SINGH, D.K. Triazole compounds in horticulturae. New Delhi: Agrotech Publishing Academy, 2001. 120p.

SWAMY, J.S. Flowering manipulation in mango: a science comes of age. Journal of Today's Biological Sciences: Research and Review, New Delhi, v.1, n.1, p.122-137, 2012. Available from: $<$ http://www.jtbsrr.in/files/documents/1st-JTBSRR-V1-I1.pdf $>$. Accessed: Feb. 02, 2016.

TAIZ, L.; ZEIGER, E. Fisiologia vegetal. 4.ed. Porto Alegre: Artmed, 2009. 819p. 